Journal of The Indonesian Nutrition Association p-ISSN: 0436-0265 e-ISSN: 2528-5874

http://ejournal.persagi.org/index.php/Gizi_Indon

\title{
KONSELING OLEH KADER POSYANDU MENINGKATKAN PRAKTIK IBU DALAM PEMBERIAN MAKAN BAYI DAN ANAK USIA 6-24 BULAN DI DESA PAGELARAN, KECAMATAN CIOMAS, BOGOR, INDONESIA
}

\section{Counseling by Posyandu Cadres Improves Mother Feeding Practices of Infant and Children at 6-24 Months of Age in Pagelaran Village, Ciomas Subdistrict, Bogor, Indonesia}

\author{
Siti Mutia Rahmawati' ${ }^{1}$, Siti Madanijah'2, Faisal Anwar' ${ }^{2}$, Risatianti Kolopaking ${ }^{3}$ \\ ${ }^{1}$ Politeknik Kesehatan Kemenkes Jakarta II \\ 2Departemen Gizi Masyarakat Fakultas Ekologi Manusia IPB Bogor \\ ${ }^{3}$ Universitas Islam Negeri Syarief Hidayatullah Jakarta \\ E-mail: mutiatita_22@yahoo.com
}

\section{ABSTRACT}

The feeding practices of infants and children (PMBA) at the age of 6-24 months should be done correctly and appropriately. Errors in feeding in this period may cause malnutrition and stunted. The purpose of this study was to determine the effect of counseling by Posyandu cadres on changes in infant and child feeding practices (PMBA) done by mothers among infants and children aged 6-24 months. Quasiexperimental research design with one group pre-post test design was applied and envolving 78 mothers of infants and children aged 6-24 months. Data on feeding practices of infants and children were obtained by interviewing mothers using a structured questionnaire covered data of mothers, babies and children, health status and growth, and the practice of breastfeeding and complementary feeding as well as hygiene were also collected. PMBA practices were then being scored covered all indicators, then categorized into 3 groups : being good if the score $>=80$, enough $60-79.9$ and less if the score is $<60$. Ttest and Wilcoxon rank test were used at the significance level of 0.05 . The average value of infant and child feeding practices by caregivers before counseling was 70.0 and increased to 75.2 after counseling. PMBA practices of mothers categorized as good increased from $25.3 \%$ to $46.7 \%$. This study showed that there was an effect of counseling on the improvement of feeding practices for baby by mother/ caregivers $(p<0.01)$. In conclusion counseling carried out by Posyandu cadres may improve the practice of PMBA by mother for their infants and children at the aged 6-24 months.

Keywords: posyandu cadre, feeding practice, nutrition counseling, children aged 6-24 months

\section{ABSTRAK}

Praktik pemberian makanan pada bayi dan anak (PMBA) usia 6- 24 bulan harus dilakukan secara benar dan tepat. Kesalahan pemberian makanan di periode tersebut dapat mengakibatkan masalah gizi kurang dan balita pendek. Tujuan penelitian ini adalah mengetahui pengaruh konseling oleh kader Posyandu terhadap perubahan praktik pemberian makan bayi dan anak (PMBA) ibu bayi dan anak usia 6-24 bulan. Desain penelitian kuasi eksperimen dengan one group pre-post test design melibatkan 78 sampel ibu dari bayi dan anak usia 6-24 bulan. Data praktik pemberian makan bayi dan anak oleh ibu diperoleh dengan cara wawancara dengan menggunakan kuesioner terstruktur yaitu data ibu, bayi dan anak, status kesehatan dan pertumbuhan, dan praktik pemberian makan ASI dan MPASI serta kebersihan. Praktik PMBA dilakukan skoring terhadap seluruh indikator, kemudian dikategorikan menjadi 3 kelompok menjadi baik bila skor $>=80$, cukup $60-79.9$ dan kurang bila skor $<60$. T-test dan uji Wilcoxon pada derajat kemaknaan 0.05 . Nilai rata-rata praktik pemberian makan bayi dan anak oleh ibu sebelum diberikan konseling adalah 70,0 dan meningkat menjadi 75,2. Praktik PMBA ibu dengan kategori baik dari 25,3 persen meningkat menjadi 46,7 persen. Hal ini menunjukkan ada perbedaan nilai pre dan post konseling $(p=0.003)$ dan ada pengaruh konseling terhadap peningkatan praktik pemberian makan bayi dan anak oleh ibu $(p<0.01)$. Konseling yang dilakukan oleh kader Posyandu dapat meningkatkan praktik PMBA ibu bayi dan anak usia 6-24 bulan.

Kata kunci: kader posyandu, pemberian makan, konseling gizi, anak usia 6-24 bulan 


\section{PENDAHULUAN}

W HO dan UNICEF memberikan rekomendasi tentang 4 standar emas pemberian makan bayi dan anak (PMBA) yang tercantum dalam Global Strategy for Infant and Young Child Feeding yaitu memberikan air susu ibu (ASI) kepada bayi segera dalam waktu 30 menit setelah bayi lahir, memberikan ASI saja atau pemberian ASI secara eksklusif sejak lahir sampai bayi berusia 6 bulan, memberikan makanan pendamping air susu ibu (MPASI) sejak bayi berusia 6 bulan sampai 24 bulan serta meneruskan pemberian ASI sampai anak berusia 24 bulan atau lebih. ${ }^{1}$

Makanan Pendamping Air Susu Ibu (MPASI) adalah makanan atau minuman yang mengandung zat gizi yang diberikan pada bayi atau anak usia 6-24 bulan guna memenuhi kebutuhan gizi selain ASI. MP-ASI merupakan makanan peralihan dari ASI ke makanan keluarga. Pengenalan dan pemberian MP-ASI harus dilakukan secara bertahap baik bentuk maupun jumlahnya, sesuai dengan kemampuan bayi. Pemberian MP-ASI yang cukup kualitas dan kuantitasnya penting untuk pertumbuhan fisik dan perkembangan kecerdasan anak yang sangat pesat pada periode ini, tetapi sangat diperlukan hygienitas dalam pemberian MP-ASI tersebut. Sanitasi dan hygienitas MP-ASI yang rendah memungkinkan terjadinya kontaminasi mikroba yang dapat meningkatkan risiko atau infeksi lain pada bayi. ${ }^{2}$

Praktik pemberian makanan pada bayi dan anak usia 6- 24 bulan harus dilakukan secara benar dan tepat. Kesalahan pemberian makanan di periode tersebut dapat mengakibatkan masalah gizi kurang dan balita pendek. Menurut laporan RISKESDAS 2013 balita gizi kurang di Indonesia tercatat sebesar 19,6 persen dan hasil Riskesdas 2018 menurun mejadi 17,7 persen. Masalah balita pendek yaitu stunting sebesar 37,2 persen pada tahun 2013 dan menurun menjadi 30,8 persen dari hasil Riskesdas 2018. Besaran prevalensi gizi kurang dan stunting di Jawa Barat masih di bawah angka nasional namun tetapi angka stunting masih di atas 20 persen. Kejadian gizi kurang dan stunting meningkat pada kelompok bayi dan anak usia 6 bulan sampai 35 bulan.3,4 Masih rendahnya praktik pemberian makan bayi dan anak yang tepat sangat terkait dengan pengetahuan, sikap dan motivasi yang dimiliki oleh ibu. Unicef (2012) menyatakan salah satu faktor sulitnya melakukan penanganan gizi kurang di Indonesia adalah pengetahuan ibu/pengasuh yang tidak memadai dan praktikpraktik pemberian makanan yang tidak tepat. ${ }^{5}$ Hal tersebut terjadi karena kurangnya informasi tentang manfaat ASI, MP-ASI, cara mengatasi kesulitan menyusui dan masalah lainnya sehingga perlu intervensi peningkatan pengetahuan gizi ibu melalui edukasi gizi.

Contento (2011) menyatakan bahwa perubahan perilaku/praktik pemberian makan dipengaruhi oleh faktor internal seperti persepsi, nilai-nilai kepercayaan yang dianut, pemahaman, sikap norma-norma sosial, kepercayaan diri, kesukaan dan sensori. Selain itu faktor luar seperti ketersediaan pangan dan pengaruh lingkungan juga dapat mempengaruhi perilaku seseorang. Perilaku makan seseorang terjadi melalui kegiatan yang terus berulang sehingga menjadi suatu kebiasaan. Kebiasaan makan individu akan berkembang menjadi kebiasaan makan keluarga dan pada akhirnya dapat berkembang menjadi kebiasaan makan kelompok atau masyarakat. Intervensi edukasi gizi mampu memperbaiki faktor-faktor tersebut dan terjadi perubahan perilaku yang diinginkan. ${ }^{6}$

Penelitian konseling tentang pemberian makan bayi dan anak dilakukan kepada ibu sebagai responden serta melihat perubahan perilakunya menunjukkan hasil yang positif. Systematic review yang dilakukan Sunguya. et al. (2013) menunjukkan setelah diberikan konseling, mampu meningkatkan perilaku ibu seperti memperbaiki higiene sanitasi persiapan makanan, frekuensi pemberian makan, bentuk/kekentalan bubur, meningkatnya jumlah asupan makanan sehingga pertumbuhan anak menjadi lebih baik dan mengurangi resiko kejadian gizi kurang. ${ }^{7}$ Noviati et al. (2006) menyatakan bahwa konseling gizi mampu meningkatkan pengetahuan, sikap dan praktek ibu serta berdampak baik pada pertumbuhan bayi dan anak. ${ }^{8}$

Pendidikan gizi individu secara konseling menggunakan metode dan teknik yang ada serta pengembangan strategi baru untuk tercapainya tujuan perilaku yang baru. ${ }^{9}$ Pelatihan konseling pemberian makan bayi dan anak (PMBA) untuk kader memiliki keunikan dalam hal proses pembelajaran. Sebagai 
peserta, kader diminta aktif dan saling berbagi pengalaman dalam memecahkan masalah pemberian makan bayi dan anak khususnya pada usia 6-24 bulan sebagai bagian dari 1000 Hari pertama kehidupan (HPK). Setiap pengalaman dan pendapat kader diperhatikan dan dihargai. Kader juga melakukan uji coba praktik konseling sesama peserta sebelum praktik langsung pada ibu dengan menggunakan keterampilan konseling dan alat bantu sehingga dapat meningkatkan kemampuan, motivasi dan persepsi kader tentang pemberian makan bayi dan anak. ${ }^{10}$

Saat ini belum ada penelitian yang mempelajari kemampuan konseling kader setelah diberikan pelatihan konseling pemberian makan bayi dan anak (PMBA) dan dampaknya terhadap praktik pemberian makan bayi dan anak oleh ibu/pengasuh. Tujuan penelitian ini adalah mengetahui efek konseling oleh kader Posyandu terhadap perubahan praktik pemberian makan bayi dan anak (PMBA) ibu bayi dan anak usia 6-24 bulan.

\section{METODE PENELITIAN}

Penelitian ini menggunakan desain kuasi eksperimen dengan one group pre-post test design, dilaksanakan pada bulan OktoberDesember 2017. Lokasi penelitian terletak di Desa Pagelaran, Kecamatan Ciomas, Kabupaten Bogor. Penentuan lokasi penelitian dilakukan secara purposif berdasarkan desa yang memiliki kader aktif terbanyak dan kesediaan desa khususnya kader dan ibu sebagai subjek penelitian. Persetujuan etik penelitian dikeluarkan oleh Komisi Etik Penelitian dari Institut Pertanian Bogor Nomor 05/IT3.KEPMSM-IPB/SK/2017.

Populasi target dalam penelitian ini adalah ibu yang mempunyai anak usia 6-24 bulan. Jumlah sampel adalah 78 ibu yang memiliki bayi dan anak usia 6-24 bulan. Jumlah sampel ditetapkan dengan rumus besar sampel menurut Sastroasmoro (1995). ${ }^{11}$ Kriteria inklusi sampel adalah 1). ibu yang memiliki bayi dan anak kelompok usia yaitu 6-9 bulan, 9-12 bulan, 12-24 bulan 2). Anak tidak dalam keadaan sakit 3). Bersedia mengikuti tahapan penelitian.

Jenis data yang dikumpulkan adalah data primer, yaitu data karakteristik ibu dan anak terdiri dari nama ibu, pendidikan dan umur ibu, nama anak, jenis kelamin dan umur anak, data kesehatan umum anak dan berat badan anak serta praktik kebersihan. Data praktik pemberian makan bayi dan anak oleh ibu diperoleh dengan cara wawancara dan observasi dengan menggunakan kuesioner terstruktur yaitu data ibu, bayi dan anak, status kesehatan dan pertumbuhan, dan praktik pemberian makan ASI dan MPASI serta kebersihan. Kuesioner di adopsi dari modul PMBA Kemenkes (2014) menjadi kuesioner PMBA 6-24 bulan.

Penilaian pemberian makan pada bayi dan anak 6 sampai 24 bulan dilakukan dengan cara menilai frekuensi pemberian $\mathrm{ASI}$, frekuensi pemberian dan besar porsi MP-ASI, menilai bentuk makanan, variasi serta kebersihan. Frekuensi menyusui dan makan adalah berapa kali bayi dan anak diberi ASI dan MP-ASI dalam sehari dan besar porsi/jumlah makanan serta bentuk makanan lumat/ lunak semipadat/padat/makanan selingan yang dikonsumsi per hari dikumpulkan dengan menggunakan kuesioner terstruktur. Variasi/keragaman makanan dalam MP-ASI adalah jumlah kelompok makanan yang dikonsumsi anak dalam sehari. Kelompok makanan untuk menilai keragaman terdiri dari 4 yaitu: padi-padian atau umbi-umbian,daging-dagingan, dan hewan lainnya termasuk telur dan susu sebagai sumber zat besi, kacang-kacangan atau polong-polongan, sayur-sayuran dan buahbuahan sumber vitamin A. Pemberian MP-ASI memenuhi keragaman MP-ASI jika anak diberikan 4 kelompok makanan dalam sehari (makanan 4 bintang*). Pemberian konseling dilakukan oleh 26 kader kepada 78 ibu yang memiliki bayi dan anak usia 6-24 bulan. Setiap ibu dikunjungi dan dberi konseling sebanyak 2 kali dalam waktu 2 bulan sehingga diperoleh data praktik PMBA sebelum dan sesudah dilakukan konseling.

Kegiatan konseling menggunakan metode konseling Pemberian Makanan Bayi dan Anak (PMBA) yang dikembangkan oleh Direktorat Gizi Kemenkes RI. Tahapan pelaksanaan edukasi PMBA melalui tiga tahapan langkah, yaitu: 1). Kader melakukan kunjungan rumah melakukan pengumpulan data praktik pemberian MPASI, 2). Kader melakukan penilaian terhadap praktik yang dilakukan ibu menggunakan formulir penilaian PMBA, 3). Kader melakukan konseling menggunakan 
metode 3 langkah konseling PMBA, yaitu pertama; menggali informasi praktik pemberian makanan, kedua; menganalisa dan menyimpulkan praktik yang dilakukan ibu/pengasuh, ketiga; melakukan tindakan konseling sesuai dengan permasalahan yang dialami ibu dengan menggunakan alat bantu kartu konseling. Tenaga Konseling adalah Kader Posyandu yang telah diberikan pelatihan tentang konseling PMBA, berjumlah 26 kader, dengan rasio 1:3 (1 kader untuk 3 ibu/pengasuh). dilakukan dengan frekuensi 2 kali selama 2 bulan, waktu yang digunakan dalam setiap kali konseling adalah 30 menit. Kader sebagai konselor telah mendapat pelatihan konseling PMBA yang dilakukan selama 3 hari dengan materi utama tentang ASI, MP ASI, Pemantauan pertumbuhan dan Teknik konseling. Pelatihan dilakukan di 3 ruang kelas pesantren Al Huda desa Pagelaran selama tiga hari, jam $8.00-17.00$. Materi diberikan dengan metode ceramah, tanya jawab, bermain peran, diskusi kasus, dan praktik tentang ASI, MPASI, pengisian KMS dan konseling PMBA. Setiap ruang kelas 8-10 orang kader dengan 2 Fasilitator nasional PMBA serta 1 asisten peneliti sebagai pendamping.

Data yang diperoleh lapangan, diolah melalui beberapa tahap yaitu editing, coding, entry, cleaning dan analisis. Coding dilakukan dengan cara menyusun code-book sebagai panduan entri dan pengolahan data. Entry data dilakukan setelah kode dibuat selanjutnya dilakukan cleaning data untuk memastikan tidak ada kesalahan dalam memasukkan data. Data diolah dan dianalisis dengan menggunakan program Microsoft Excell versi 2010 dan Statistical Programme for Social Sciences (SPSS) IBM seri 23. Data tentang karakteristik sampel dilakukan analisis distribusi frekuensi, sedangkan data indikator praktik PMBA, yaitu pemberian ASI, frekuensi menyusui, frekuensi makan, jumlah porsi, bentuk makanan, variasi makanan dan praktik higiene dikategorikan menjadi sesuai dan tidak sesuai rekomendasi. Selanjutnya untuk mengetahui tingkat praktik PMBA dilakukan skoring terhadap seluruh indikator, kemudian dikategorikan menjadi 3 kelompok menjadi baik bila skor $>=80$, sedang 60-79.9 dan kurang bila skor $<60$. Untuk mengetahui pengaruh konseling terhadap praktik pemberian makan bayi dan anak oleh ibu antara pre dan post intervensi digunakan uji normalitas Kolmogorov-Smirnov dan dilanjutkan dengan uji $T$ dan uji Wilcoxon untuk melihat perbedaan dua buah data yang berpasangan dengan derajat kemaknaan 0,05.

\section{HASIL}

Hasil penelitian menunjukkan jumlah ibu yang mempunyai data lengkap untuk diolah sejumlah 75 orang. Ibu berumur antara 16-43 tahun dan 50,7 persen ibu berpendidikan SLTA dan diploma.

Tabel 1

Karakteristik Ibu, Bayi, dan Anak Usia 6-24 Bulan

\begin{tabular}{cc}
\hline Karakteristik & $\begin{array}{c}\text { Kelompok Bayi dan anak } \\
\text { usia 6-24 bulan }\end{array}$ \\
\hline Usia ibu (tahun ) N (\%) & $35(46,7)$ \\
$-\quad<30$ tahun & $40(53,3)$ \\
$-\quad>30$ tahun & \\
Pendidikan ibu N (\%) & $16(21,3)$ \\
$-\quad$ SD & $21(28,0)$ \\
$-\quad$ SMP & $26(34,7)$ \\
$-\quad$ SMA & $12(16,0)$ \\
$-\quad$ PT (Diploma) & \\
Usia Bayi dan anak & $22(29,3)$ \\
$-\quad 6-9$ bulan & $23(30,7)$ \\
$-\quad 9-12$ bulan & $30(40,0)$ \\
$-\quad$ - $2-24$ bulan & \\
Jenis Kelamin bayi dan anak (\%) & $49(65,4)$ \\
$-\quad$ Laki-laki & $26(34,6)$ \\
\hline
\end{tabular}


Tabel 2

Status Kesehatan dan Pertumbuhan Bayi dan Anak Usia 6-24 Bulan

\begin{tabular}{lcc}
\hline Kriteria & $\begin{array}{l}\text { Usia 6-24 bulan pre } \\
\mathrm{N}(\%)\end{array}$ & $\begin{array}{l}\text { Usia 6-24 bulan post } \\
\mathrm{N}(\%)\end{array}$ \\
\hline $\begin{array}{l}\text { Status Kesehatan satu bulan } \\
\text { terakhir }\end{array}$ & & \\
$\quad$ - Tidak sehat & $34(45,3)$ & $26(34,7)$ \\
- Sehat & $41(54,7)$ & $49(65,3)$ \\
Status Pertumbuhan & & $0(0)$ \\
- BGM & $0(0)$ & $2(2,7)$ \\
- 2T & $1(1,3)$ & $4(5,3)$ \\
- Tidak ada KMS & $3(4,0)$ & $18(24,0)$ \\
- Tidak Naik & $21(28,0)$ & $23(30,7)$ \\
- Naik & $29(38,7)$ & $28(37,3)$ \\
- Data tidak lengkap & $21(28,0)$ & \\
\hline
\end{tabular}

Jenis kelamin kelompok bayi dan anak usia 6-24 bulan sebagian besar $(65,4 \%)$ adalah lakilaki dengan kelompok umur paling banyak adalah anak usia 12-24 bulan sebanyak 40 persen (Tabel 1). Pada kelompok usia 6-24 bulan, kondisi kesehatan anak pada kunjungan pertama (pre) sebanyak 54,7 persen adalah sehat. Sedangkan bayi dan anak dalam keadaan tidak sehat (diare, flu, batuk dan demam) sebanyak 45,3 persen. Kondisi kesehatan bayi dan anak menjadi lebih baik pada kunjungan ke 2 (post). Hasil penilaian KMS berupa status pertumbuhan anak, hanya 38,7 persen anak yang memiliki status pertumbuhan naik $(\mathrm{N})$, sebanyak 28,0 persen anak tidak naik berat badannya dibandingkan berat badan bulan yang lalu dan masih ada bayi dan anak sebesar 28,0 persen yang tidak lengkap data berat badannya sehingga tidak diketahui status pertumbuhannya. Status pertumbuhan bayi dan anak pada kunjungan ke 2 (post) dengan status naik menurun menjadi 30,7 persen, serta kasus bayi dan anak dengan tidak naik 2 kali berturut-turut (2T) bertambah 1 orang. Selengkapnya dapat dilihat pada Tabel 2.

Kualitas praktik pemberian ASI dan MPASI dapat dilihat dari 15 indikator, yaitu masih diberikan ASI, frekuensi menyusui, frekuensi makan, porsi pemberian MP-ASI, bentuk dan variasi makanan yang diberikan, makanan pokok, sayur dan buah, kacang-kacangan, lauk hewani, selingan, respon aktif, mencuci tangan, masak air, merokok. Hasil penelitian menunjukkan kualitas praktik pemberian makan pada bayi dan anak usia 6-24 bulan masih belum optimal. Pemberian ASI masih dilanjutkan pada 85,3 persen bayi dan anak usia 6-24 bulan dengan frekuensi menyusui lebih dari 8 kali sehari (72,0\%) sebelum diberikan konseling (pre) dan pada kunjungan kedua terjadi peningkatan jumlah ibu yang memberikan ASI dengan frekuensi lebih dari 8 kali sehari menjadi 77,3 persen namun jumlah ibu yang memberikan ASI menurun menjadi 83,5 persen.

Frekuensi pemberian makan pada sebagian besar bayi dan anak sudah sesuai dengan usia yaitu 76,0 persen pada kondisi pre sebelum diberikan konseling dan meningkat menjadi 89,3 persen pada post (setelah diberikan konseling pada kunjungan 2). Sebelum diberikan konseling, hampir separuh bayi dan anak usia $6-24$ bulan $(49,3 \%)$ tidak mendapatkan porsi makan yang sesuai dengan usianya dan terjadi penurunan pada post (kunjungan 2 )menjadi 40,0 persen.

Demikian halnya dengan bentuk makanan, pada kondisi pre konseling sebanyak 41,3 persen bentuk makanan yang diberikan tidak sesuai dengan usia bayi dan anak namun pada post konseling (kunjungan 2) menjadi lebih baik yaitu terjadi penurunan menjadi 14,6 persen. Bentuk makanan untuk bayi umur 6-9 bulan adalah bubur kental atau lumat, namun bubur yang diberikan masih encer. Ibu masih beranggapan bubur encer lebih mudah di cerna oleh bayi. Pada kelompok bayi umur 9-12 bulan seharusnya diberikan makanan yang lebih padat dan kasar seperti nasi tim, namun masih banyak ibu yang memberikan bubur. Demikian halnya pada kelompok anak usia 12-24 bulan 
seharusnya bentuk makanan seperti makanan keluarga atau orang dewasa, namun masih ada yang memberikan bubur atau nasi lembik. Sebagian besar bayi dan anak sudah diberikan makanan selingan dan cara ibu memberikan makan sudah memperhatikan responsiv aktif dari anaknya, yaitu ibu tidak memaksa anak makan, ibu sabar dan memperhatikan tandatanda anak mau makan.

Tabel 3

Praktik Pemberian Makan Bayi dan Anak Usia 6-24 Bulan

\begin{tabular}{|c|c|c|}
\hline Kegiatan & $\begin{array}{c}\text { Pre-test } \\
\mathrm{n}(\%)\end{array}$ & $\begin{array}{c}\text { Post-test } \\
\mathrm{n}(\%)\end{array}$ \\
\hline \multicolumn{3}{|l|}{ Diberikan ASI } \\
\hline Tidak & $11(14,7)$ & $13(17,3)$ \\
\hline Iya & $64(85,3)$ & $62(83,5)$ \\
\hline \multicolumn{3}{|l|}{ Frekuensi menyusui } \\
\hline$<8$ kali sehari & $21(28,0)$ & $17(22,7)$ \\
\hline$\geq 8$ kali sehari & $54(72,0)$ & $58(77,3)$ \\
\hline \multicolumn{3}{|l|}{ Frekuensi makan } \\
\hline Tidak sesuai & $18(24,0)$ & $8(10,7)$ \\
\hline Sesuai & $57(76,0)$ & $67(89,3)$ \\
\hline \multicolumn{3}{|l|}{ Porsi makan } \\
\hline Tidak sesuai & $37(49,3)$ & $30(40,0)$ \\
\hline Sesuai & $38(50,7)$ & $45(60,0)$ \\
\hline \multicolumn{3}{|l|}{ Bentuk makanan } \\
\hline Tidak sesuai & $31(41,3)$ & $11(14,6)$ \\
\hline Sesuai & $44(58,7)$ & $64(85,4)$ \\
\hline \multicolumn{3}{|l|}{ Variasi makanan } \\
\hline 4 bintang & $16(21,3)$ & $20(26,7)$ \\
\hline$<4$ bintang & $59(78,7)$ & $55(73,3)$ \\
\hline \multicolumn{3}{|l|}{ Makanan pokok } \\
\hline Tidak & $0(0)$ & $0(0)$ \\
\hline Iya & $75(100)$ & $75(100)$ \\
\hline \multicolumn{3}{|l|}{ Sayur Buah } \\
\hline Tidak & $21(28,0)$ & $25(33,3)$ \\
\hline lya & $54(72,0)$ & $50(66,7)$ \\
\hline \multicolumn{3}{|l|}{ Kacang-kacangan } \\
\hline Tidak & $40(53,3)$ & $43(57,3)$ \\
\hline lya & $35(46,7)$ & $32(42,7)$ \\
\hline \multicolumn{3}{|l|}{ Hewani } \\
\hline Tidak & $33(44,0)$ & $16(21,3)$ \\
\hline lya & $42(56,0)$ & $59(78,7)$ \\
\hline \multicolumn{3}{|l|}{ Selingan } \\
\hline Tidak & $7(9,3)$ & $4(5,3)$ \\
\hline lya & $68(90,7)$ & $71(94,7)$ \\
\hline \multicolumn{3}{|l|}{ Responsiv aktif } \\
\hline Tidak & $8(10,6)$ & $6(8,0)$ \\
\hline lya & $67(89,4)$ & $69(92,0)$ \\
\hline \multicolumn{3}{|c|}{ Kebiasaan mencuci tangan } \\
\hline Tidak & $8(10,7)$ & $3(4,0)$ \\
\hline lya & $67(89,3)$ & $72(96,0)$ \\
\hline \multicolumn{3}{|l|}{ Masak air } \\
\hline Tidak & $5(6,7)$ & $1(1,3)$ \\
\hline lya & $70(93,3)$ & $74(98,7)$ \\
\hline \multicolumn{3}{|l|}{ Merokok di rumah } \\
\hline Merokok & $34(45,3)$ & $34(45,3)$ \\
\hline Tidak merokok & $41(54,7)$ & $41(54,7)$ \\
\hline
\end{tabular}


Kesehatan bayi dan anak ditentukan oleh banyak faktor, selain pemberian makan yang benar faktor lingkungan khususnya praktik kebersihan di sekitar rumah perlu mendapat perhatian. Hasil penelitian pada Tabel 3 menunjukkan kualitas praktik kebersihan keluarga masih perlu ditingkatkan. Sebagian besar keluarga (khususnya ibu dan anak) sudah memiliki kebiasaan mencuci tangan sebelum makan dan memasak air sampai matang untuk keperluan bayi dan anak. Kebiasaan yang tidak baik lainnya adalah hampir separuh keluarga, khususnya ayah memiliki kebiasaan merokok didalam rumah dan kebiasaan buruk tersebut akan berdampak kepada kebersihan udara sekitar rumah. Praktik pemberian makan selengkapnya dapat dilihat pada Tabel 3 .

Hasil penelitian menunjukkan variasi/keragaman makanan yang diberikan pada bayi dan anak usia 6-24 bulan harus terdiri dari 4 kelompok makanan atau 4 bintang $\left(^{*}\right)$ yaitu makanan pokok, sayur dan buah sumber vitamin $A$, makanan hewani sumber zat besi dan kacang-kacangan. Dari hasil penelitian menunjukkan sebelum diberikan konseling hanya 21,3 persen bayi dan anak yang diberikan makanan dengan variasi 4 bintang, namun pada kunjungan kedua (post konseling) meningkat menjadi 26,7 persen. Semua bayi dan anak (100\%) mengkonsumsi makanan pokok sebelum dan setelah konseling. Terdapat penurunan konsumsi sayur dan buah sebagai sumber vitamin A setelah konseling dilakukan.Tidak sampai separuh bayi dan anak usia 6-24 bulan diberikan kacang-kacangan dalam makanan setiap harinya $(46,7 \%)$. Ada peningkatan konsumsi hewani setelah diberikan konseling. (Gambar 1)

Pada Tabel 4 menunjukkan telah terjadi peningkatan nilai praktik pemberian makan bayi dan anak oleh ibu sebelum dan setelah diberikan konseling oleh kader. Sebelum diberikan konseling, nilai rata-rata praktik pmba ibu adalah 70,0 sedangkan nilai praktik setelah diberikan konseling adalah 75,2. Hal ini menunjukkan ada perbedaan nilai praktik pemberian makan bayi dan anak ibu sebelum dan setelah diberikan konseling $(p<0.05)$.

Hasil penelitian menunjukkan terjadi peningkatan presentase berdasarkan kategori praktik pemberian makan bayi dan anak oleh ibu sebelum dan setelah diberikan konseling oleh kader. Sebelum diberikan konseling, praktik pmba ibu dengan kategori baik hanya 25,3 persen. Sedangkan praktik pmba ibu dengan kategori baik setelah diberikan konseling meningkat menjadi 46,7 persen. Hal ini menunjukkan ada pengaruh konseling terhadap peningkatan praktik pemberian makan bayi dan anak usia 6-24 bulan oleh ibu berdasarkan kategori $(p<0.01)$.

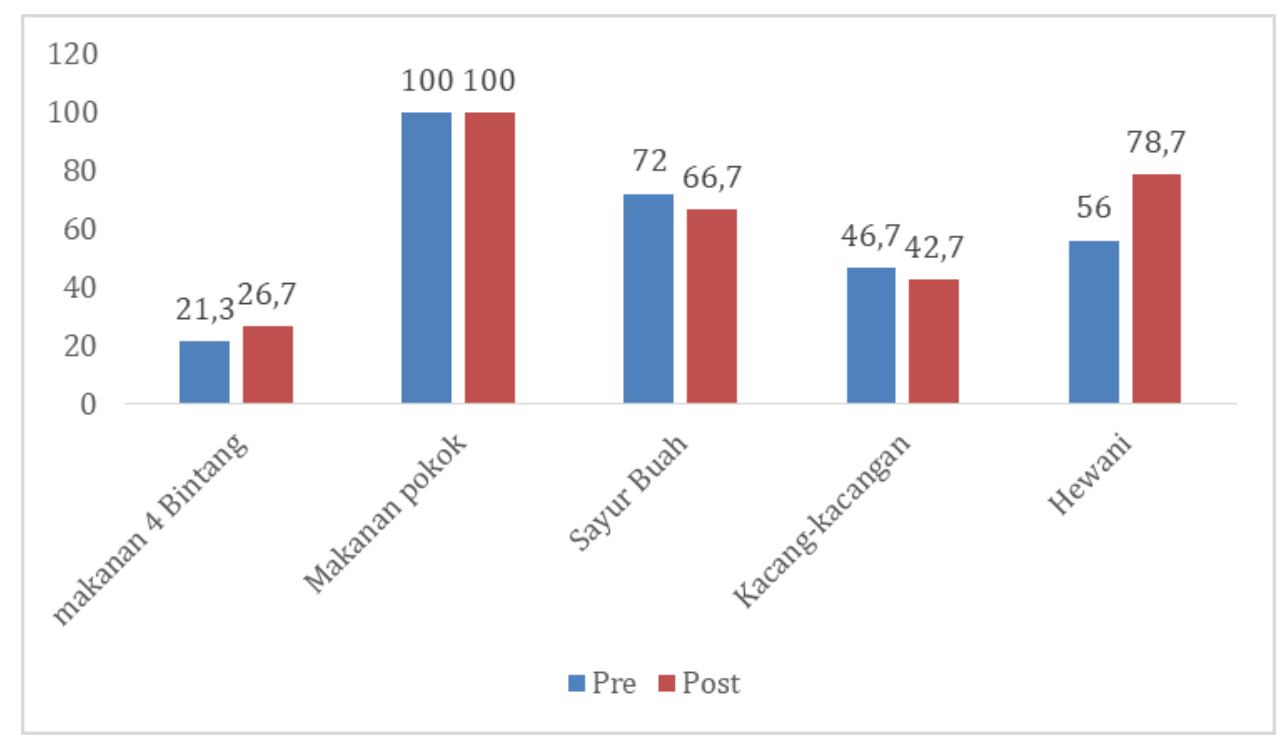

Gambar 1

Variasi/Keragaman Makanan Bayi dan Anak Usia 6-24 Bulan 
Tabel 4

Pengaruh Konseling terhadap Praktik Pemberian Makan Bayi dan Anak Usia 6-24 Bulan

\begin{tabular}{|c|c|c|c|}
\hline Nilai & $\begin{array}{c}\text { Pre-test } \\
\mathrm{n}(\%)\end{array}$ & $\begin{array}{c}\text { Post-test } \\
\mathrm{n}(\%)\end{array}$ & Nilai $p$ \\
\hline Rata-rata Praktik $\pm S D$ & $70,0 \pm 12,0$ & $75,2 \pm 11,6$ & $p=0.003^{*}$ \\
\hline \multicolumn{4}{|l|}{ Praktik PMBA } \\
\hline Baik & $19(25,3)$ & $35(46,7)$ & $p=0.000^{* *}$ \\
\hline Cukup & $41(54,7)$ & $36(48,0)$ & \\
\hline Kurang & $15(20,0)$ & $4(5,3)$ & \\
\hline
\end{tabular}

\section{BAHASAN}

Pada saat memberikan makan pendamping $\mathrm{ASI}$, ada beberapa faktor yang harus diperhatikan oleh ibu, yaitu usia bayi lanak, frekuensi pemberian, jumlah porsi, bentuk/kekentalan/tekstur, variasi, respon aktif dan kebersihan.10 Semakin bertambah usia maka kebutuhan gizi bayi dan anak semakin meningkat sehingga jumlah makan pun harus bertambah sesuai usia. Hampir separuh ibu bayi dan anak memberikan jumlah makanan yang tidak sesuai dengan usia dan pemberian konseling belum bisa meningkatkan praktik PMBA khususnya jumlah porsi. Jika jumlah porsi makanan kurang dari kebutuhan maka dapat berdampak pada pertumbuhan bayi dan anak yaitu berat badan tidak naik. Masalah tersebut dikemukakan oleh Patil et al. (2016) bahwa frekuensi, jumlah dan konsistensi/bentuk makanan masih bermasalah sehingga penting diberikan edukasi kepada ibu yang memiliki bayi diatas 6 bulan tentang pengetahuan pemberian makan bayi dan anak. ${ }^{12}$

Hasil penelitian menunjukkan bahwa masih banyak ibu yang memberikan makanan pendamping ASI (MP-ASI) dengan bentuk makanan yang tidak tepat dan tidak sesuai dengan usia anak. Hasil ini sesuai dengan studi di Sukabumi bahwa bentuk makanan yang diberikan masih belum sesuai karena ibu masih merasa kuatir jika memberikan bayi dengan tekstur kental. ${ }^{13}$

Variasi/keragaman makanan yang diberikan ibu masih sangat kurang, hanya 1 dari 5 ibu yang memberikan makanan 4 bintang setiap kali makan pada saat sebelum diberikan konseling dan berubah menjadi 1 dari 4 ibu memberikan makanan anak dengan menu 4 bintang yaitu mengandung bahan makanan pokok, makanan hewani sumber zat besi, kacang-kacangan dan hasil olahnya serta sayur buah sebagai sumber vitamin A. Penelitian lain menunjukkan kesamaan tentang pola pemberian MP ASI usia 6-23 bulan di Aceh bahwa kualitas pemberian MP ASI masih rendah. Dari 4 indikator yang digunakan hanya frekuensi makan dan kesesuaian usia yang sudah baik, sedangkan keragaman dan jumlah makanan yang diberikan masih sangat rendah. ${ }^{14}$

Konsumsi sayur dan buah sebelum dan setelah konseling ternyata menurun, alasan ibu tidak memberikan sayur dan buah karena anaknya sedang diare. Hasil ini tidak sesuai dengan penelitian Saha (2015) yang menyatakan bahwa efek konseling dapat meningkatkan konsumsi sayur dan buah dan konseling dilakukan 2 sampai 4 kali. Konseling pribadi merupakan alat komunikasi perubahan perilaku yang bermanfaat meningkatkan praktikpraktik pemberian makan bayi dan anak. ${ }^{15}$

Ada peningkatan presentasi ibu yang memberikan makan dengan frekuensi yang benar, porsi sesuai, bentuk makanan yang benar serta variasi makan setelah diberikan konseling. Hasil ini sesuai dengan penelitian di Pakistan yang menyatakan bahwa konseling gizi pada ibu bisa meningkatkan praktik pemberian makanan yaitu variasi, bentuk/kekentalan dan peningkatan konsumsi makanan sumber hewani. ${ }^{16}$ Penelitian di Kenya menunjukkan pemberian konseling kepada orangtua dapat merubah praktik pemberian makan anak khususnya jumlah variasi makanan. ${ }^{17}$ Hasil studi ini sesuai dengan hasil systematic review oleh Sunguya. et al. (2013) menunjukkan setelah diberikan konseling kepada ibu mampu meningkatkan perilaku ibu seperti memperbaiki higiene sanitasi persiapan 
makanan, frekuensi pemberian makan, bentuk/kekentalan bubur, meningkatnya jumlah asupan makanan sehingga pertumbuhan anak menjadi lebih baik dan mengurangi risiko kejadian gizi kurang. ${ }^{7}$

Hasil Riskesdas 2018 tentang keragaman makanan bayi dan anak usia 6-23 bulan di Indonesia yang sudah memenuhi syarat sebesar 46,6 persen. ${ }^{4}$ Kondisi seperti ini akan mempengaruhi kualitas pemberian MP ASI dan pada akhirnya akan berpengaruh terhadap pertumbuhan dan perkembangan anak. Asupan protein merupakan faktor risiko untuk terjadinya pertumbuhan dan hambatan perkembangan pada anak. ${ }^{18}$ Hasil kajian Beal T. et al. (2018) tentang pemberian makanan pendamping ASI di Indonesia menyatakan bahwa variasi makanan khususnya pemberian makanan hewani sebagai sumber zat besi dapat menurunkan resiko stunting pada anak. ${ }^{19}$

Penyiapan makanan dan pemberian makan lebih banyak dilakukan oleh ibu karena sebagian besar ibu tidak bekerja dan ibu sudah memperhatikan kebersihan diri sendiri seperti cuci tangan, memasak air sampai matang serta memperhatikan respon anak (anak menunjukkan tanda mau makan dan tidak dipaksa). Hal-hal lain yang perlu diperhatikan dalam mempersiapkan dan menyimpan makanan yang aman adalah (1) jagalah kebersihan tangan, tempat dan alat masak/makan,(2) pisahkan makanan yang sudah dimasak dengan makanan mentah (3) gunakan makanan yang segar dan masak sampai matang (daging, ayam, telur dan ikan) (4) Simpan makanan dalam suhu yang tepat sesuai jenis makanan dan dalam keadaan bersih, hindari pencemaran debu dan binatang,(5) menggunakan air bersih yang aman. ${ }^{10}$

Hasil penelitian menunjukkan telah terjadi peningkatan nilai dan kategori praktik pemberian makan bayi dan anak usia 6-24 bulan oleh ibu sebelum dan setelah diberikan konseling oleh kader. Hasil ini tidak sesuai dengan penelitian Ochola et al. (2012) yang menyatakan bahwa satu sesi konseling dengan pendampingan tidak cukup untuk mempertahankan pemberian ASI eksklusif. ${ }^{20}$ Hasil penelitian di Semarang menunjukkan bahwa konseling laktasi yang intensif yaitu sebanyak 4 kali pada saat pranatal dan dan 5 kali sebanyak postnatal berpengaruh terhadap peningkatan pengetahuan, perubahan sikap dan peningkatan jumlah ibu yang memberikan ASI eksklusif sampai umur 3 bulan. ${ }^{21}$

Namun hasil penelitian Arini et al. (2017) menyatakan pemberian edukasi kepada ibu dapat meningkatkan perilaku pemberian MPASI. ${ }^{22}$ Studi di Uganda menunjukkan bahwa pendidikan gizi secara signifikan berdampak pada pengetahuan ibu dalam hal persiapan makanan anak, sikap, dan praktik pemberian makan. ${ }^{23}$ Berdasarkan hasil ini menunjukkan konseling yang dilakukan oleh kader dapat meningkatkan praktik pemberian makan bayi dan anak pada ibu dan harus seiring dengan peningkatan pengetahuan, sikap dan motivasi ibu melalui proses konseling berkelanjutan oleh kader seperti hasil penelitian Azzahra et al. (2015) yang menyatakan bahwa konseling pertumbuhan dan pemberian makan yang diberikan pada lbu meningkatkan pengetahuan dan sikap tentang pemberian MP-ASI untuk anak usia 6-24 bulan. ${ }^{24}$ Penelitian di Cameeron menunjukkan konseling PMBA yang diberikan oleh kader yang telah dilatih menjadi konselor, efektif dalam meningkatkan Asi eksklusif dan mengurangi risiko stunting pada anak 6-8 bulan. ${ }^{25}$

Pelatihan konseling pmba untuk kader merupakan pelatihan pertama kali yang diterima oleh kader. Kegiatan konseling yang diberikan oleh kader posyandu pada ibu merupakan komunikasi dua arah secara interpersonal dengan suasana tenang, sehingga lbu menjadi lebih terbuka untuk menceritakan permasalahan gizi dan kesehatan anaknya. Konsep konseling melalui komunikasi dua arah juga dapat meningkatkan pengetahuan ibu sebagai dasar proses perubahan perilaku. ${ }^{26}$ Proses konseling menggunakan 3 langkah yaitu 1) kader sebagai konselor berusaha menggali informasi sebanyak mungkin dari ibu 2) kader menganalisa informasi yang disampaikan ibu dan menyimpulkan sehingga diketahui permasalahannya,3) kader melakukan tindakan dengan memberikan informasi/pengetahuan dan saran sesuai dengan permasalahan ibu. ${ }^{10}$

Ibu menilai konseling yang dilakukan oleh kader bermanfaat untuk menambah pengetahuan ibu. Kader menggunakan media kartu konseling (KK) pada saat melakukan tindakan (langkah ke 3 konseling PMBA) dan memberikan leaflet kepada ibu di akhir konseling. Pada akhir konseling, kader kembali 
menanyakan pemahaman ibu dan mendorong ibu untuk melakukan tindakan perbaikan praktik pemberian makan pada bayi dan anaknya. Seharusnya kegiatan konseling tidak cukup dilakukan hanya sekali, perubahan praktik PMBA yang terjadi mungkin masih sebatas mencoba perilaku baru, perlu konseling lebih lanjut sampai ibu dapat melestarikan perilaku baru dalam hidupnya. ${ }^{10}$

Penelitian ini memiliki keterbatasan yaitu, peneliti tidak melakukan uji coba kuesioner praktik pemberian makan bayi dan anak usia 6-24 bulan karena diadopsi langsung dari modul konseling pemberian makan bayi dan anak (PMBA) Kemenkes tahun 2014. Peneliti juga tidak melakukan analisis variabel perancu seperti pendidikan dan umur ibu dan sumber informasi lainnya yang dapat mempengaruhi hasil praktik PMBA ibu. Konseling dalam penelitian ini hanya dilakukan dua kali, untuk melihat pengaruh konseling terhadap perubahan perilaku perlu dilakukan beberapa kali konseling.

\section{SIMPULAN DAN SARAN}

\section{Simpulan}

Konseling pemberian makan bayi dan anak (PMBA) yang dilakukan oleh kader posyandu mampu meningkatkan nilai praktik PMBA ibu bayi dan anak usia 6-24 bulan. Peningkatan terjadi pada praktik pemberian makan bayi dan anak ibu bayi dan anak usia 6-24 bulan, khususnya tentang peningkatan konsumsi lauk hewani, bentuk/kekentalan dan variasi makanan.

\section{Saran}

Berdasarkan keterbatasan penelitian, penelitian selanjutnya disarankan untuk mempelajari faktor yang mempengaruhi praktik pemberian makan bayi dan anak usia 6-24 bulan. Meskipun konseling oleh kader secara signifikan mampu meningkatkan praktik pemberian makan bayi dan anak namun perlu diperhatikan pendampingan dan atau perhatian dari petugas kesehatan terhadap praktik konseling, sehingga kader tetap termotivasi untuk secara rutin melakukan konseling sehingga perubahan perilaku ibu dalam PMBA menjadi kebiasaan yang dilakukan setiap hari.

\section{UCAPAN TERIMA KASIH}

Ucapan terima kasih disampaikan kepada ibu-ibu kader Posyandu dan ibu-ibu bayi dan anak usia 6-24 bulan di desa Pagelaran Ciomas Bogor atas partisipasi dalam penelitian ini. Terima kasih kepada Bapak Camat Ciomas, kepala Puskesmas Ciomas dan kapala desa Pagelaran atas ijinnya menggunakan wilayah kerja sebagai tempat penelitian.

\section{RUJUKAN}

1. UNICEF. Global Strategy for Infant and Young Child Feeding. Geneva.: World Health Organisation-UNICEF; 2003.

2. Mufida L Widyaningsih TD, Maligan JM. Prinsip dasar MPASI untuk bayi usia 624 Bulan. Jurnal Pangan dan Agroindustri ,2015; 3 (4);:.1646-1651.

3. Kementerian Kesehatan RI . Laporan Hasil Riset Kesehatan Dasar Tahun 2013. Jakarta. (ID): Pusat Penelitian dan Pengembangan Gizi dan Makanan. Balitbangkes;2013.

4. Kementerian Kesehatan RI. Hasil utama Riset Kesehatan Dasar Tahun 2018. Jakarta. (ID): BadanPenelitian dan Pengembangan Kesehatan;2018.

5. UNICEF. United Nation Children Fund Indonesia. Ringkasan Kajian Gizi Ibu dan Anak: isu-isu penting;2012.

6. Contento IR.. Nutrition Education: Lingking Theory and practice. 2Ed. Canada;Jones and Bartlett Publisher; 2011.

7. Sunguya BF, Poudel KC, Mlunde LB, Shakya $P$, Urassa DP, Jimba M\&Yasuoka J. Effectiveness of nutrition training of health workers toward improving caregivers' feeding practices for children aged six months to two years: a systematic review. Nutrition journal, 2013;12(1): 1-14.

8. Noviati, Susanto JC, Selina H, Mexitalia $M$. The influence of intensive nutritional counseling in Posyandu towards the growth 4-18 month old children. 
Paediatrica Indonesiana, 2006;46(34):57-63.

9. Kulwa KBM, Verstraeten R, Bouckaert $\mathrm{KP}$, Mamiro SP, Kolsteren $\mathrm{PW}$ and Lachat $\mathrm{C}$. Effectiveness of a nutrition education package in improving feeding practices, dietary adequacy and growth of infants and young children in rural Tanzania: rationale, design and methods of a cluster randomised trial. BMC Pub Health .2014.; 14(1):1077.

10. Kementerian Kesehatan RI. Modul Pelatihan Pemberian Makan Bayi dan Anak untuk Petugas Kesehatan dan Kader.Jakarta (ID): Direktorat Bina Gizi, Direktorat Jenderal Bina Gizi dan KIA; 2014.

11. Sastroasmoro S, Ismail S. Dasar-dasar metodologi penelitian klinis. Jakarta (ID): Binarupa Aksara;1995.

12. Patil N, Bawa R, Patil RR. Study of complementary feeding practices in mothers of infants age 6-12 months. International Journal of Pediatric Research. 2016;3. ISSN 2349-5499.

13. Nurwulansari $F$, Sunjaya $D$, Gurnida DA. Analisis hasil jangka pendek pelaksanaan konseling pemberian makan bayi dan anak menggunakan pemodelan RASCH. Gizi Indon. 2018;41(2):85-96

14. Ahmad A. Efektifitas model edukasi gizi dengan kartu monitoring makanan dan biscuit MP-ASI terhadap pertumbuhan dan status anemia pada anak gizi kurang usia 6-23 bulan di Aceh. [Disertasi]. Bogor (ID); Program Pascasarjana Institut Pertanian Bogor.2018.

15. Saha C, Chowdhury AR, Nambiar VS. Effect of personalized counseling as a tool for behaviour change communication for improving the nutritional status and IYCF practices of children (0-5 years) in under 5 clinic and day care centre, South 24 Parganas West Bengal...JJFANS. 2015;4(3):86-96.

16. Zaman S, Ashraf R, Martines J. Training in complementary feeding counselling of health care workers and its influence on maternal behaviours and child growth: a cluster randomized controlled trial in Lahore, Pakistan. Journal Health Popular Nutrition. 2008; 26(2):210-222.
17. Félicitée $\mathrm{N}$, Andreas $\mathrm{C}$, Rodrigues $\mathrm{N}$, Njong TN, Roger D. Feeding practices and impact of nutritional counseling coupled with home-based follow-up on the knowledge of mothers of children hospitalized for severe acute malnutrition. The Journal of Medical Research. 2018;4(1): 42-47.

18. Garg A, Chadha R. Community-Based Nutrition Counseling Improves Complementary Feeding Practices and Growth of Infants (6-12 Months) in Rural Uttar Pradesh, India. J Hum Nutr Food Sci.2016;4(5): 1099.

19. Beal T, Tumilowicz A, Sutrisna A,lzwardy $D$, Neufeld L. A review of child stunting determinants in Indonesia. Matern Child Nutr. 2018; e12617. https://doi.org/10.1111/mcn.12617

20. Ochola SA, Labadarios D, Nduati RW. 2012. Impact of counselling on exclusive breast-feeding practices in a poor urban setting in Kenya: a randomized controlled trial. Public Health Nutrition.2012: 16(10), 1732-1740

21. Ambarwati $R$, Muis SF, Susantini $P$ 2013. Pengaruh konseling laktasi intensif terhadap pemberian air susu ibu (ASI) eksklusif sampai 3 bulan. Gizi Indo.2013; 2(1): 15-23.

22. Arini FA, Sofianita NI, Bahrul IM. Pengaruh pelatihan pemberian MP ASI kepada ibu dengan anak Baduta di Kecamatan Sukmajaya Kota Depok terhadap pengetahuan dan perilaku pemberian MP ASI. Jurnal Kedokteran dan Kesehatan. 2017;.13(1); 80-89.

23. Nabugoomu. J, Namutebi. A, Kaaya. AN, Nasinyama. G. Nutrition education influences child feeding knowledge attitudes and practices of caregivers in Uganda. American Journal of Health Research. 2015;3(2); 82-90. doi: 10.11648/j.ajhr.20150302.15

24. Azzahra FM, Muniroh L. Pengaruh konseling terhadap pengetahuan dan sikap pemberian MP-ASI. Media Gizi Indonesia. 2015;10 (1): 20-25.

25. Reinsma K,Nkuoh G, Nshom E. The potential effectiveness of the nutrition improvement program on infant and young child feeding and nutritional status in the Northwest and Southwest regions 
of Cameroon, Central Africa. BMC Health Services Research. 2016; 16(1);654.
26. Persatuan Ahli Gizi (PERSAGI). Konseling Gizi.Jakarta(ID): Penebar plus; 2013. 